\title{
First Months in Teaching-Novices Relate to Their Difficulties
}

\author{
Ditza Maskit \\ Gordon College of Education, Haifa, Israel \\ Email: ditzamaskit@gmail.com \\ Received March 12 ${ }^{\text {th }}$, 2013; revised April 10 $0^{\text {th }}$,2013; accepted April 25 $5^{\text {th }}, 2013$
}

\begin{abstract}
Copyright ( 2013 Ditza Maskit. This is an open access article distributed under the Creative Commons Attribution License, which permits unrestricted use, distribution, and reproduction in any medium, provided the original work is properly cited.
\end{abstract}

\begin{abstract}
The study aimed to identify the main hardships and challenges encountered by teaching interns and the ways in which they cope with these difficulties, as they emerged from personal diaries that the interns kept in the first year of teaching. Findings from the diaries identified the following main categories of hardship on entering the profession: 1) difficulties in the personal dimension, including difficulties involved in navigating between private and professional lives; 2) difficulties in the personal-professional dimension relating to the transition from the status of student to the status of internship; 3) difficulties in the inter-personal dimension including communication with colleagues and parents and a sense of isolation; 4) difficulties in the professional dimension including coping with the complexity of teaching, handling a class and burdensome workloads. The findings also relate to coping strategies employed by the interns to cope with these difficulties. Early pre-service teaching including exposure to the difficulties involved in teaching may facilitate initial work experiences, lessen the shock of the first plunge into the classroom and reduce the phenomenon of early dropout from the profession.
\end{abstract}

Keywords: Internship; Interns’ Coping Strategies; Interns’ Hardships; Interns’ Diaries

\section{Theoretical Background}

\section{Entry into the Teaching Profession}

To enter the teaching profession is to cross a bridge between an incomplete experience, teaching under controlled conditions as an intern and the assumption of all the obligations of the real world of the classroom and the school. Although teaching is perceived as a formative experience both before practical training starts (Lortie, 1975; Weinstein, 1990), and throughout the training course (Britzman, 1991; Stoeber \& Rennert, 2008), the actual entry stage is nonetheless important in developing a fuller and more realistic perception of teaching (Cochran-Smith, 2004) and in forming attitudes and perceptions vis-à-vis the unique characteristics of the profession. This stage begins the shaping of the teacher's professional development that will continue throughout their career (Gaudelli \& Ousley, 2009; Johnson, 2004; Loughran, 2004). Research relating to the first year of teaching ${ }^{1}$ indicates that it exposes the novice teacher to information concerning teaching work and its complexity, the broad spectrum of its roles, the great responsibility and commitment it involves, and the variety of people engaged in this profession.

Additionally research on this stage of the profession discusses circles that support interns (Colley, 2002; Feiman-

\footnotetext{
${ }^{1}$ It is noted that concepts such as "interns", "Newly Qualified Teachers (NQT)", "beginners" and "novices" are all used in the relevant research literature to relate to new teachers during the first stage of their professional work. In Israel a distinction is drawn between interns (experiencing their first year of teaching in the educational system) and novice teachers who have successfully completed the first probationary year, yet are still considered to be newcomers to the profession. The present study relates to interns in their first year of teaching.
}

Nemser, 1983; Harrison, Dymoke, \& Pell, 2006; Hawkey, 1997; Hobson, Hobson, Malderez, Kerr, Tracey, Pell, \& Tomlinson, 2005; Kyriacou \& Kune, 2007; Leshem, 2008; Rippon, \& Martin, 2006; Schmidt, \& Knowles, 1995; Wang, 2000) and relates to the difficulties facing interns and novice teachers at the inception of their teaching career. Predominant among these difficulties are "organizational difficulties" expressed in encounters with the organizational culture of the schools, including the principals and the role that they play (Spindler \& Biott, 2000; Kelchtermans \& Ballet, 2002). Novice teachers voice the expectation that the school's organizational culture will be clear and supportive, and the work environment will promote personal and professional fulfillment, valuing the newcomer personally and professionally (Friedman, 2004; Gavish \& Friedman, 2010). Since research has shown that the school's organizational culture and the novice's encounter with it are both formative factors for their careers as teachers, difficulties in first encounters with the organization can produce disappointment and frustration for new teachers. Such difficulties may include assignment of the teacher to a large number of classes, a split timetable and awkward hours, expectations to perform the same duties and responsibilities as experienced teachers (Andrews, Gilbert \& Martin, 2007; Angelle, 2006; DarlingHammond, 2003), as well as assignments to teach student populations with behavioral and academic problems. An additional area of difficulty mentioned in the research literature relates to student "discipline problems" and class management (Hobson, Malderez, Tracey, Giannakaki, Pell, \& Tomlinson, 2008; Jarvis \& Algozzine, 2006; Jarvis \& Algozzzine, 2006; Kyriacou \& Kune, 2007). Other difficulties relate to the new teacher's teaching abilities, including difficulties regarding 
lesson preparation, adapting the teaching to the class level and the extent of the students' interest, and relations with parents (Sánchez, Rosaes, \& Cañedo, 1999; Romano, 2004; Veenman, 1984). Jarvis and Algozzine (2006) relate to difficulties that arise concerning content and curriculum knowledge, student evaluation, and the design of tests, quizzes, and other instruments to evaluate what the students have achieved (Athanases \& Achinstein, 2003).

The burden of extra-role factors imposed on the interns must also be considered as a difficulty expressed in time constrictions, onerous paperwork, a need for planning time, non-instructional duties, long role-related and non-role-related meetings (Gilbert, 2005; Jarvis \& Algozzzine, 2006). Other studies show that the intern's "status" in the school may cause difficulty, especially when novices sense alienation and isolation in the school, and they need emotional support to overcome these feelings (Austin-Huling, 1992; Harrison, Lawson \& Wortley, 2005a, 2005b; Stanulis, Burrill, \& Ames, 2007).

The difficulties reviewed above and the ways in which new teachers cope with them constitute an indivisible part of their early work in school.

In the last decade in Israel, much thought and activity has been invested in studying the first stages of a teacher's career and programs have developed to improve orientation and support for novice teachers. Given these developments it becomes important to identify typical difficulties that arise when the intern enters the teaching profession.

The present study therefore focused on the following questions:

Which main difficulties characterize the first year of teaching work?

Which strategies are employed by interns to cope with the difficulties they are exposed to in their first work year?

\section{Entry into the Teaching Profession in Israel}

In order to be accredited with a teaching certificate from the Ministry of Education all new teachers in Israel must experience a one-year internship (the induction). During this period, they are defined as interns and required to work at least $1 / 3$ of the statutory hours of a full-time teacher. Two circles support the intern during their internship year: 1) Each new teacher is assigned a mentor from the school. The mentor is expected both to support and assist the interns, to supervise their work and to conduct a formative and summative assessment of their progress as a teacher ${ }^{2}$ (Ministry of Education, 2000); 2) Interns participate in a weekly support workshop at one of the teacher education institutions (university or college). Interns are awarded a license to practice the teaching profession after complying successfully with the evaluation and completing all internship duties. After obtaining their license the interns become novice teachers for a period of two years. The introductory stage of teaching in Israel is therefore spread over a period of three years and the present study deals only with the first year of entry into teaching - the year of internship.

\section{The Research Method}

\section{Participants}

Participants were 50 interns; 45 females and 5 males, chosen

${ }^{2}$ These processes are performed through observation, and mentoring sessions providing feedback and operative suggestions. as a purposeful sample (Patton, 2002) to represent the intern population participating in intern support workshops in an optimal manner. The population was drawn from three weekly support workshops operating in three teacher training institutes. All participants expressed interest and involvement in the writing of their journals. All of them had just finished their training and had been assigned to elementary schools as interns.

\section{Data Collection}

The research presents an analysis of the interns' reflections as they were recorded in their diaries during the first month of their internship year. Their reflections recorded the experiences of the processes they underwent during this year. Personal diaries have been employed as a research tool in previous studies to inquire into the lives of interns through their reflective writing (Gilar, Maria de los Angeles \& Castejón, 2007; Stoughton, 2007) and have been used to describe the practical experiences of students, novice teachers and teachers in general (Clark \& Lampert, 1990; Duckworth, 1977; Francis, 1995; Gilar, et al., 2007; Kitching, Morgan, \& O’Leary, 2009; Leavy, McSorley, \& Boté, 2007; Leshem \& Trafford, 2006; Maskit \& Yaffa, 2010; Sykes \& Bird, 1992). Keeping a diary and recording reflections on their experiences makes it possible for narrators to develop a critical attitude and to take a second look at events (Connelly \& Clandinin, 1988; Connelly et al., 1997; Handal \& Lauvas, 1987) and to develop critical thinking. This process enables teachers to study and evaluate themselves and consequently to develop their skills (Lampert \& Clark, 1990; Sykes \& Bird, 1992). The reflective thinking of the interns concerning their work served as a primary source allowing the researcher to gain a "backstage" view of their trials and experiences.

As part of their participation in the weekly support workshop, participants were asked to keep an open personal diary. Each intern was asked to send a detailed personal weekly report (a total of 4 reports for a month) to the group instructor by e-mail. The reports described processes they experienced in their teaching work during that week. Interns were not required to relate to any specific subjects, so that the choice of subjects and manner of description and the scope and timing of the events, writing style etc. were left to their discretion. The workshop supervision read the diary entries and provided feedback at least twice a month. The findings of the present research are based on the 50 diaries of the participants, including 400 weekly reports that were sent to the supervisors during the first two months of their internship.

\section{Analysis and Interpretation of Findings}

Qualitative content analysis was applied to the findings (Patton, 2002), allowing the author to examine the data as a whole, identifying themes and grouping them into categories. This strategy allows the researcher to observe and understand the writers' individual worlds through their writing (Elbaz-Luwisch, 2002; Richardson, 1994), and to infer insights from the content (Clandinin, 1986; Cochran-Smith \& Lytle, 1990; Strauss \& Corbin, 1994). This analysis has been employed in various research studies to understand the new teacher's world (Butt \& Raymond, 1989; Floden \& Huberman, 1989; Hargreaves, 1995; Smedley, 1995).

After analyzing the content, through open coding (Strauss, 1987) several subjects were found to recur with conspicuous 
frequency, allowing the identification of a number of categories and components. The unit of analysis was the "episode"-a limited independent content unit relating to a single event or reference.

The qualitative analysis focused on the difficulties to which the interns were exposed in their work and the coping strategies they employed to deal with these difficulties. Other content categories including inter alia the supportive workshop, the relationship between the intern and the workshop mentor, and the interns' evaluation process, were separated from the overall system of data and were not included in the derivation of the findings. The findings were therefore only based on some of the categories collected during the research.

Each participant signed a consent form. Confidentiality of all details was strictly maintained and anonymity of the interns was ensured.

\section{Findings}

Analysis of the diaries revealed that the interns experienced various types of difficulties during their first year in teaching and employed various coping strategies to deal with each of these difficulties. The identified types of difficulties and coping strategies are now described by category and illustrated with quotations from the diaries. All names are fictitious.

\section{Difficulties in the Personal Dimension}

One of the intial personal difficulties that most interns immediately face on entry into the teaching profession is their doubt concerning their ability to maneuver between the demands of work and family. During their studies as pre-service teachers they looked forward to become professional teachers as well as parents, but they often did not realize how difficult it would be to cope simultaneously with the demands of both family and workloads:

I was worried about the long journeys to and from school and the restricted free time I would have with my new born baby (Michelle);

I didn't know how I'd manage to be both a teacher and a mother (Daphne).

I waited three years to become a mother, I thought that I would manage to work as a teacher while raising children but dealing with the reality is quite shocking. I have no time, no money and many demands; it is so hard (Dora).

This dilemma is echoed in words of Shir: "I can't stay after school hours because my child's kindergarten closes at exactly 13:00" and of Shani "the school is far from my home... I arrive barely breathing... in college I began to study at 9:00, but now I have to arrive earlier", while a male teacher, Alon writes: "I can't do this financially, buying additional software for geography, and I don't have the reservoir of computer programs that I had in college”. Rama explained the difficulty she experienced:

When I studied in college I was a student and students are allowed absences in up to $20 \%$ of the lessons... it was a good arrangement. This week my baby felt bad but I couldn't stay at home, I don't have a $20 \%$ allowance. I had to go to the class... the class had a maths exam and I had no replacement.

Rama explained the mechanisms she employed to cope with this situation:

I went to work feeling bad that a "stranger" was looking after my baby. This feeling accompanied me until I entered the classroom. When I saw the children I understood that I wasn't neglecting my daughter. I'm simply a teacher with commitment and responsibility. This thought comforted me.

This perception of the importance of her role as a teacher made it easier for her to cope with the difficulty. Other diaries described similar situations:

In the end I ordered the new software that I needed for teaching. Although it was at the expense of my family I understood that I needed the program for my regular work, to advance and succeed at work... I decided to buy the program despite the cost (Alon).

I understood that if I wanted to do my work properly, to have time to talk with the students, colleagues, I needed to stay an extra hour... I asked the babysitter to stay longer so that I could function better in school... I understood it was an investment (Hagit).

These contents reveal that the interns tend to base their arrangements on their perception of their role as teachers including their sense of the responsibility and commitment required for the profession. This perception, professional in substance, represents the beginning of a professional progression and serves as a lever for the interns' decision-making, when coping with the need for commitment to their role as teachers despite their family commitments.

\section{Difficulties in the Personal-Professional Dimension}

The interns' narratives revealed that the transition from being a student to becoming a teacher constitutes a predominant difficulty in the first year of teaching. This was described extensively throughout all the diaries, and especially in the first weeks of their work.

Anat wrote:

The era of being a student ended. Instructions ended. There are other commitments I am a teacher in a classroom; if I don't plan I won't know what to teach. I can no longer afford not to understand because I am the one who has to explain. It was easier to be a student because I could allow myself "concessions". I was given consideration because I was a student; I was allowed not to know, not to understand. Now that's no longer so. It's a rapid change, just yesterday I was a student and today I'm already a teacher. I have to quickly get used to it and to ensure that the students don't feel I'm a new teacher and don't relate to me like a student teacher visiting the class.

Anat experienced the significance of "being a teacher". The responsibility involved in being a teacher is well described in her diary, in contrast to her time as a student. The diary revealed that Anat understood that being a teacher means arriving at the class on time, planning lessons, and establishing her new status as a teacher. Later she described the strategies that she adopted to succeed in this mission:

I felt that I needed to find a way that would help me to progress... I decided to proceed step by step. I prepared a chart, I recorded all the tasks that I needed to perform, the resources that could help me, the time that it would take to perform the tasks and all the time I was telling myself "now I'm a teacher".

Anat used structured tactics and conducted a dialogue with herself concerning the change that had occurred in her status.

Yael $^{3}$ describes the transition from the status of student to that of a teacher from a different viewpoint. She misses the

${ }^{3}$ A detailed analysis of Yael's diary was described in another article (Maskit \& Dickman, 2006). 
college, which constituted a safe place for personal growth and describes the difficulty involved in the transition to teaching: I understand why this transition is difficult for me. In the college I always felt safe, a sense of confidence... I felt comfortable in the college, felt secure to do things and experiment, even when I had problems... I always had someone to talk to, I felt that they listened to me, that I could tell them and be understood. ... even when I had problems or made mistakes, I felt that in the college they reinforced me... The difference is that now I can't make mistakes, and there is no-one with whom I can talk or ask advice at the class I can get advice from my mentor only after the lesson ... I don't have someone to "watch over me".

Later she wrote:

In college when I was a student I only wanted to be a teacher and now this transition worries me. They taught me everything in the college... to teach, to plan, to set goals, to consider the students, to educate the students... suddenly I have to perform everything I was taught. To be a teacher, to act as they taught me and I cannot make a mistake.

The difficulty involved in the transition to teaching that mainly relates to a lack of confidence, isolation, and a sense that as a teacher "you cannot make a mistake" was also evident in other places in Yael's diary. Later on she described how she copes with this transition:

As a student I wanted to be like my teachers, they had professional power, knowledge, and pedagogic knowledge. They knew how to teach, to explain... when I was a student the mentor teacher solved the problems... now the problems are mine, so I decided to be clear when I instructed the students; to do things slowly but surely.

This solution, coping in stages and in a focused manner was proposed in several of the diaries, and suggested as an effective solution on the way to becoming a teacher'.

An additional area of difficulty in the personal-professional dimension that all the interns described in their diaries was a sense of isolation and alienation in the school: "I'm really alone" (Yael); "in contrast to the college, I feel foreign and 'other'” (Anat).

Mostly they coped with loneliness and alienation with the help of their mentor teacher. Interns indicated that the mentor's support was very significant; explaining how the mentor became a "professional friend", increasing their motivation to teach:

When I meet with my mentor I feel that she improves my motivation, challenges me to work better and resolves my feeling of isolation (Tamar).

Recently I've noticed that she [the mentor] listens to me and helps me in precisely those situations where I'm having problems and difficulties (Annette).

She assists me all the time, she really listens, she really provides the help I need (Yael). She has become a real friend at school, a professional friend helping me (Galya).

The weekly workshops constituted the second support circle. The diaries frequently referred to the supportive workshops provided by the training colleges as important resources, which improved the interns' ability to think more deeply.

From time to time I ran into problems... I talked about them at the workshop and the other intern s suggested recommendations and solutions from different angles... This is a most helpful aspect of the workshop, different ways to solve a problem. (Tamar).

From the very first workshop session I felt that the advice and guidance, direction, help and experience was essential to keep difficulties to a minimum during the first year (Susan);

I got so much encouragement and support from the workshops, it provided strength and help for this difficult entry into the profession. I felt that the workshop was the most practical part of all (Annette).

The workshop also helped interns to overcome their difficulties and increased motivation to teach: "Every Wednesday after the workshop I feel stronger, more motivated” (Gil); “I'm eager to go into class on Thursday and to try out what I've heard and what I've learned." (Iris).

The experience of being together at the workshops, as a group of interns, provided the interns with a deep sense that their experiences were generic and common to all beginners in the profession.

The workshop is the most significant meeting of the year. I wait for it every week so that I can meet with all the other interns. I feel that they understand what I'm talking about, and I can speak freely (Adele).

The workshop was my meeting place; I felt I was waiting for it all week to meet my colleagues and to know that I wasn't the only one with problems (Galia);

I sat in the workshop with girls who studied at the college with me, not as classmates this time but as colleagues in the teaching profession... Everything I thought I'd never tell anyone burst out. I heard about my friends' troubles, we spoke, and I recovered. Everyone spoke about their troubles and we soon found we had common problems and tried to solve them together, supporting each other, and it helped (Rachel).

The awareness that other interns had common hardships helped them to expose their problems, to ask for help, to talk about their work, and eventually to find independent solutions.

\section{Difficulties in the Interpersonal Dimension}

Many of the interns indicated that they had difficulty communicating with colleagues in the school. For example it was obvious that they found it difficult to integrate socially and professionally with other teachers: "I have no one to talk with, they ignore me in the staff lounge” (Anat); "I can't catch a teacher and speak with her. They are in one circle and I'm in another circle" (Orna); I try to join in the conversation in the teachers' lounge but my voice is not heard” (Michal); "I turned to one of the maths teachers in school asked her to help me to plan my lesson... she told me to ask someone else who understood the subject better" (Shani); "I asked N. how to create groups in my class and she uttered two sentences and walked away" (Naomi); "its very difficult in the staff lounge... I don't know where to sit... I can't find anyone to talk to... I'm continually wondering how to change the situation” (Galia). Yael related: All week long I tried to get help from the teachers in school. They promised to help me but very quickly I understood that I was alone”. Noa wrote:

I was so pleased that the history teachers decided to compose joint work papers. Before the meeting I prepared things at home, I listed challenging suggestions for assignments. I looked up materials. In the meeting I saw that we weren't communicating on the same wavelength. Almost all the teachers didn't listen to my suggestions at all, one teacher looked at the page I had written but did not say anything.

The diaries revealed that the other teachers often related to the interns with apathy and that the interns found it difficult to 
communicate with the staff. In her descriptions of strategies that she used to cope with this phenomenon, Tamar explained how she chose to bring new materials to school that she had acquired at college as a way to negotiate:

I approached the homeroom teacher in the class parallel to mine, I told her about the new learning program that I had studied in college and suggested giving her the disc about the program and this opened up a conversation... later she sat down beside me during the recess and it was already easier.

Shani volunteered to buy a present in the name of all the teachers:

No-one volunteered. Each teacher said that she was busy and had no time, so I volunteered to buy it... it opened a good channel of communication with the teachers... everyone said that I had chosen well and there was already something to talk about.

Adi had asked her "mentor teacher to sit with me and another teacher to plan the lesson and then we were already a threesome of teachers and later I turned to her by myself and we went over it again together".

Other communication problems related to the relations between the intern and the students' parents. Chen explained:

In the parents' meeting I already felt that they were not with me, even a little opposed to me. They asked how many years of experience I had, I asked for volunteers for the class committee and no one responded... I despaired that I hadn't managed to form a relationship with the parents. I had no committee... I didn't know what to do.

Chen felt that that she had no go-between to link her with the parents and that she "had lost any ability to do something with the parents" and so she decided to act in a different way: "I decided to phone the parents according to the list... in the end two of them agreed. Now I have a committee and I hope it will help". It is clear from Chen's words that she did not give up and chose to act in an orderly and controlled manner. In this way she succeeded in changing the situation and creating a new start for her relationship with the parents.

Certain expressions were repeated in other diaries, such as "the parents test me, if I give homework I get phone calls to my home telling me that the teacher in the parallel class doesn't give homework" (Dana); "I announced that there would be an exam on Friday and already in the evening I received five phone calls from parents that I shouldn't give an exam because the students are stressed by the subject matter" (Alon); "there are parents who consistently wait for me by the classroom door with a list of complaints" (Rachel).

The message that the parents did not trust the interns aroused a sense of lack of confidence and unrest for the interns. "I don't know what to do" (Rachel); "sometimes I get angry at them and feel that they don't rely on me as a teacher" (Alon); "if I needed to work according to the parents' instructions I wouldn't succeed in teaching anything in the class" (Dorit). In the attempt to cope with these feelings Rachel explained: "I decided to listen, I announced that each Tuesday I would have a free hour and if someone wanted to come and talk I would be at the school. This option that I gave them to talk with me solves some of the problems". Anat decided "to devote an hour in the evening. I told them that each day between eight and nine in the evening I would be available for phone calls. It was a good idea they phoned during those hours and we could talk in peace... I understood that to listen to the parents quietly was a professionally correct strategy that facilitated good relations with the par- ents.”

From the interns' reports it was clear that they did not usually ignore the problem but tried to find solutions to difficulties concerning their relations with the parents. The combination of boundary setting: determining an hour for conversations and their willingness to listen and implement things created the first buds of parent-teacher communication and neutralized the sense of frustration that the interns had felt.

\section{Difficulties in the Professional Dimension}

Professional difficulties pointed up in the interns' diaries focused on the professional substance of teaching in general and specific components involved in the novice teachers' work. All the diaries described teaching as difficult, complex and exhausting work: "the work is difficult, wearying, tiring and frustrating" (Yael); "It incredible what is involved in being a teacher” (Rachel) "being a teacher is so complex, I didn't think it would be so hard" (Alon); "I found myself under continuous pressure... I didn’t know where to start” (Hagit); “teaching was very difficult, unexpected... I had not been trained to deal with the difficulties" (Galit); "there are many difficulties, I teach for many hours... its difficult to teach so many hours” (Dorit).

Rachel explained:

I suddenly saw what it means to be a teacher. I needed to teach the subject matter itself and to distinguish the different levels of the students, and to solve problems of noise, and arguments between the students, and to prepare work sheets, and to ensure that we completed the subject matter, and to run between the different classes in different age groups. There were a lot of details that were all part of teaching and I found it difficult.

In her efforts to cope with this difficulty Rachel decides:

I'll work according to the book, slowly, without skipping from subject to subject, making lists... I noticed that if I work according to the book it helps me, that if I work with lists I don't forget and especially I saw that experience in the field is the best possible learning for me and that the experience itself helps me to cope with difficulties.

Rachel's words clarify that she does not succumb to difficulty, she uses certain techniques to help her cope with difficulties and the very fact that she manages to cope and her experience itself make things easier.

Controlling the class in the face of breaches of discipline was noted as a problem in all the diaries. This was expressed in statements such as: "there's noise all the time and I can't teach" (Anat); "its incredible what they can do in class and they don't even hear my voice" (Michal); "as soon as I turn to the blackboard several children get up, I'm already scared to write on the board" (Yael).

This serious difficulty led to despair, a sense of helplessness and total inability to cope.

In the last hour of the day, it's very hard. Lots of discipline problems and an unpleasant atmosphere (Aviva).

Grade 11 has thirty-one pupils, with serious discipline problems, which makes it my most difficult class. The problems appear as noise and talking during most of the lesson, [cell phone] conversations coming in during the lesson, ring tones from the mobiles, leaving the room without permission, and even during a film in the audio-visual room-the disturbances don't stop (Tali).

The discipline problem is, as I see it, a key factor in reducing 
the teacher's self-confidence. ... The discipline problem is unbearable; particularly with one pupil. I felt exhausted from the amount of attention I had to give her, it was impossible to ignore her... As a beginner in teaching, the discipline problems diminished my image/OR status in the pupils' eyes... My inability to overcome the problem became my burden (Shirley).

Nothing that I tried succeeded. I didn't manage to teach the material (Olive).

Despite their very real problems, the interns did not give up; they tried to deal with their difficulties, attempting to find solutions, for example:

I know that discipline and learning habits are no simple matter, and the more classes I encounter, the sharper this knowledge becomes... I sense that the situation in this area is getting worse, and I ask the staff I work with to help, trying to figure out the right ways to cope. Lately I have begun to think more about ways to transfer most of the responsibility to the pupil. Perhaps if the pupils know that no one else will assume this responsibility, and that success depends only on them, they will be motivated to exercise some internal discipline, rather than waiting for the external discipline the teacher imposes. But I'll admit that I'm not fully convinced that this is going to help." (Ann);

I admit that I want to learn how to hold them on a tighter leash, so to speak. I'd like to be more assertive. That's my task for next week, to see how I manage the discipline issue... This week I tried: I came into the class and I was "tough." I wrote down in the register the names of everyone who disrupted the lesson, and saw that on some it had an effect, but for most of them-those who are the cause of the trouble, it had less effect. ... But I didn't compromise, meaning: no eating during the lesson, no roaming around the room, and if someone cannot pay attention-yes, I'll send him out of the room to calm down for a few minutes (Tali).

Dorit talked about another experience relating to discipline problems:

After my lack of success, I consulted another teacher who recommended that I should punish the disruptive students. I did exactly what she told me, but it didn't help me.

Dorit's attempt to apply solutions suggested by her colleague did not help her and so she looked for other coping strategies:

I understood that I needed to do something else, something that would suit me and the relationships I had with the students. I decided to try to talk about the difficulty in individual conversations with the students. I took all the disruptive students and talked with each of them separately. That reduced some of the problems but not all.

Dorit also chose to work according to her own "credo", devoting time to individual discussions with the students. Turning to the individual students represents the educational approach that she adopted to cope with the problem.

To summarize: It seems that the diaries entries indicated that the interns understood that they could cope with discipline problems when they were related to their teaching methods, their relations with the pupils, and their pedagogical perceptions. In these cases they modified their teaching strategies, consolidating their attitude and above all decided not to give in. The interns' attempts to cope with their hardships are encouraging, since they indicate their ability to seek out solutions that will help them to improve their classroom performance.

To summarize, it appears that intern teachers in Israel encounter many difficulties, yet they find ways to cope with them.
Apparently, exposure to difficulties constitutes a typical generic and universal phenomenon in the work of new teachers.

\section{Insights and Practical Implications}

The findings of this study identify various difficulties encountered by teaching interns during their first year as teachers, and the coping strategies that they employ to deal with these difficulties. In affinity with the Israeli context it seems that despite the long training period of novice teachers that in most cases is spread over four years, interns still face many difficulties on entry into the teaching profession. It can therefore be assumed on the basis of these findings that first year hardships and difficulties experienced during induction are generic and universal characteristics. The universal concerns of interns was also illustrated in previous study in which "The messages conveyed in novices' stories deliver a holistic and inclusive portrayal of... while conveying... at the same time, a universal humanistic message about teachers and teaching” (Orland-bark \& Maskit, 2011: p. 446). Induction, as illustrated at the professional literature is a meaningful stage in teachers' professional development, during which they examine their activities, identify needs for professional development and accept personal responsibility (Vonk, 1993, 1995). The findings of the present research reflect the interns' world as they cope with the difficulties encountered on entry into the teaching profession, with their first exposure to the reality of teaching. These difficulties were categorized according to the following themes: personal, personal-professional, interpersonal and professional; together these themes produce a fuller picture of the interns' hardships and the ways in which they cope with these difficulties.

In the category of personal-professional difficulties, the difficulty involved in "the transition from the status of student to the status of teacher" appeared with the highest frequency. This finding tallies with the findings of previous research that novices, who are in the transition period from studentship to teaching occupation, have to assume a multiplicity of roles acting as a student, a teacher and a researcher (Smith \& Sela, 2005). At this stage, many interns deal with personal emotional and professional dilemmas that result directly from the passage from "being a pre-service teacher" to "being a teacher". Intern teachers wish to prove their abilities at the school and even to themselves, but they often lack the professional circumstances at work (Romano, 2008). The sense of independence that characterizes the move from the status of a pre-service teacher who depends on his instructors, to that of a stand-alone teacher often clashes with the true position of the intern at school (Schlichte, Yssel, \& Merbler, 2005).

In the category of professional difficulties, "coping with discipline and steering the class” was the difficulty most frequently noted in all the interns' diaries. This finding resembles previous findings, which have consistently revealed that classroom management is an essential component of teaching, and teachers rank it as one of their major concerns (Evertson \& Weinstein, 2006; Friedman, 2006; Raosas \& West, 2009).

An additional finding that emerged from the study was that the interns are not deterred by the difficulties they encounter and they search for strategies that can help them to cope successfully with the difficulties. The interns' diaries revealed various coping strategies employed by the interns including working in small, gradual and calculated steps. They simultanously relied on their prior knowledge, and auxiliary re- 
sources that enrich their professional world, relating both to pedagogy and their disciplinary subject matter.

Appealing for support and assistance also constituted a popular coping strategy for the interns. They mainly turned to two familiar support circles: 1) mentor teachers and 2) their colleagues in a support workshop. They did not hesitate to try to ask for help from other sources including colleagues in the school, who are willing to cooperate. Reliance on such resources for assistance as recorded in the interns' diaries is in line with other research indicating that mentoring is an important component during induction, serving as a major factor in reducing interns' negative feelings (Schlichte, Yssel, \& Merbler, 2005; Salinitri, 2005) and that support workshops also provide an important contribution to beginning teachers as they begin to become absorbed in teaching work (Harrison, Dymoke \& Pell, 2006; Ingersoll \& Strong, 2011).

Another lens of the research findings exposed the interns' ability to reflect on their work through an internal mirror, illuminating and clarifying teaching contents and processes during the first year of work in education, as a credible reflection of the interns' world. These recorded reflections indicate the interns' strong capacity to think, to reflect on professional matters and, to present an accurate picture of the teaching conditions they encounter.

Since knowledge concerning the effects of induction programs and policies is still limited (Feiman-Nemser \& Carver, 2009), it is recommended that interns conduct an ongoing reflective dialogue (recorded in a reflective diary) during their academic training and at the inception of their professional career. This dialogue can provide a channel of communication and activity that helps the intern to improve and advance professional training methods, as well as their own professional development.

As noted, in Israel, there is a three year introductory period of entry into a teaching career includes three years during which new teachers are provided with circles for support and assistance. The findings of the research reinforce the call for this long-term assistance while at the same time they indicate the important value of exposing interns to information concerning the difficulties in the field, even earlier than the practical stage, during their studies, through knowledge on the experiences of other interns, initiating discussions on this issue and even through educational encounters between interns and student teachers. The findings sharpen the understanding that suitable solutions should be provided in the early stages of their training, so that, interns can be informed about and exposed to difficulties expected in their initial work experiences and to the possible ways of coping with these difficulties. Discussion concerning these difficulties at such an early stage can help prepare student teachers for their entry into the profession and this early groundwork should assist new teachers at the inception of their career.

It seems that the statement: "What I learned in particular was how to try to cope with my difficulties. I learned that I needed to deduce conclusions from all my trials, I learned that I needed to learn more, I learned that I need to deal with decision-making, that I need to be helped, to ask, to receive help, and to cope" (Dora) points to one of the important insights from this study, that coping with difficulties is an indivisible part of the interns' work, necessitating professional learning and growth combined with an ability to ask questions and to request assistance. These can be established as stepping stones for other interns beginning their teaching career.

\section{REFERENCES}

Andrews, S. P, Gilbert, L. S., \& Martin, E. P. (2007). The first years of teaching: Disparities in perceptions of support. Action in Teacher Education, 28, 4-13. doi:10.1080/01626620.2007.10463424

Angelle, P. S. (2006). Instructional leadership and monitoring: Increasing teacher intent to stay through socialization. National Association of Secondary School Principals, NASSP Bulletin, 90, 318-334. doi:10.1177/0192636506294843

Athanases, S. Z., \& Achinstein, B. (2003). Focusing new teachers on individual and low performing students: The centrality of formative assessment in the mentor's repertoire of practice. Teachers College Record, 105, 1486-1520. doi:10.1111/1467-9620.00298

Austin-Huling, L. (1992). Research on learning to teach. Journal for Teacher Education, 43, 170-180. doi: $10.1177 / 0022487192043003003$

Bartell, C. A. (2004). Cultivating high-quality teaching through induction and mentoring. Thousand Oaks, CA: Corwin Press, a SAGE Publications Company.

Britzman, D. (1991). Practice makes practice: A critical study of learning to teach. Albany, NY: State University of New York Press.

Bullough Jr., R. V., \& Draper, R. J. (2004). Mentoring and emotions. Journal of Education for Teaching, 30, 271-288. doi:10.1080/0260747042000309493

Butler, J. (1992). Teacher professional development: An Australian case study. Journal of Education for Teaching, 18, 221-238. doi:10.1080/0260747920180302

Butt, R., \& Raymond, D. (1989). Studying the nature and development of teachers' knowledge using collaborative autobiography. International Journal of Educational Research, 13, 403-419. doi:10.1016/0883-0355(89)90037-2

Carver, C. L., \& Feiman-Nemser, S. (2009). Using Policy to improve teacher induction: Critical elements and missing pieces. Educational Policy, 23, 295-328. doi:10.1177/0895904807310036

Clandinin, D. J. (1986). Classroom practice: Teacher images in action. London: Falmer Press.

Cochran-Smith, M. (2004). Stayers, leavers, lovers, and dreamers: Insights about teacher retention. Journal of Teacher Education, 55 387-392. doi:10.1177/0022487104270188

Cochran-Smith, M., \& Lytle, S. L. (1990). Research on teaching and teacher research: The issues that divide. Educational Researcher, 19, 2-11. doi:10.3102/0013189X019002002

Connelly, F. M, Clandinin, D. J., \& He, M. F.(1997). Teachers’ personal practical knowledge on the professional landscape. Teaching and Teacher Education, 13, 665-674. doi:10.1016/S0742-051X(97)00014-0

Connelly, F. M., \& Clandinin, D. J. (1988). Teachers as curriculum planners-Narratives of experience. The Ontario Institute for Studies in Education and Teachers. New York: Columbia University.

Darling-Hammond, L. (1990). Teachers and teaching: Signs of a changing profession. In R. Houston (Ed.), Handbook of research on teacher education (pp. 267-289). New York: Macmillan Publishing Company.

Darling-Hammond, L. (2003). Keeping good teachers: Why it matters, what leaders can do. Educational Leadership, 60, 6-13.

Elbaz-Luwisch, F. (2002). Writing as inquiry: Storying the teaching self in writing workshops. Curriculum Inquiry, 32, 403-428. doi:10.1111/1467-873X.t01-1-00239

Floden, R. E., \& Huberman, M. (1989). Teachers' professional lives: The state of the art. International Journal of Educational Research, 13, 455-466. doi:10.1016/0883-0355(89)90040-2

Friedman, I. (2004). Organizational expectations of the intern teacher. Social Psychology of Education, 7, 435-461. doi:10.1007/s11218-004-3639-1

Friedman, I. (2006). Classroom management and teacher stress and bumout. In C. M. Evertson, \& C. S. Weinstein (Eds.), A handbook of classroom management: Research, practice, and contemporary issues (pp. 925-945). Mahwah, NJ: Lawrence Erlbaum Associates. 
Gavish, B., \& Friedman, I. (2010). Intern teachers' experience of teaching: A dynamic aspect of burnout. Social Psychology of Education, 13, 141-167. doi:10.1007/s11218-009-9108-0

Gilar, R., María de los Ángeles, M. R., \& Castejón, C. L. (2007). Diary-based strategy assessment and its relationship to performance in a group of trainee teachers. Teaching and Teacher Education, 23, 1334-1344. doi:10.1016/j.tate.2006.07.012

Gilbert, L. (2005). What helps beginning teachers? Educational Leadership, 62, 36-39.

Goddard, R., \& Goddard, M. (2006). Beginning teacher burnout in Queensland schools: Associations with serious intentions to leave. The Australian Educational Researcher, 33, 61-76.

doi:10.1007/BF03216834

Hargreaves, A. (1995). Development and desire. In T. Gusky, \& M. Huberman (Eds.), Professional development in education (pp. 9-35). Milton Keynes: Open University Press.

Harrison. J. K., Dymoke, S., \& Pell, T. (2006). Mentoring beginning teachers in secondary schools: An analysis of practice. Teaching and Teacher Education, 22, 1055-1067. doi:10.1016/j.tate.2006.04.021

Harrison, J. K., Lawson, T., \& Wortley, A. (2005a). Mentoring the beginning teacher: Developing professional autonomy through critical reflection on practice. Reflective Practice, 6, 419-441. doi:10.1080/14623940500220277

Harrison. J. K., Lawson, T., \& Wortley, A. (2005b). Facilitating the professional learning of new teachers through critical reflection on practice during mentoring meetings. European Journal of Teacher Education, 28, 267-292.

Hobson, A. J., Hobson, A., Malderez, K., Tracey, L., Giannakaki, M., Pell, G., \& Tomlinson, P. D. et al. (2008). Student teachers' experiences of initial teacher preparation in England: Core themes and variation. Research Papers in Education, 23, 407-433. doi:10.1080/02671520701809825

Ingersoll, R., \& Strong, M. (2011). The impact of induction and mentoring programs for beginning teachers: A critical review of the research. Review of Education Research, 81, 201-233. doi:10.3102/0034654311403323

Jarvis, S., \& Algozzine, B. (2006). Everything I need to know about teaching: They forgot to tell me! Thousands Oaks, CA: Corwin Press.

Kelchtermans, G., \& Ballet, K. (2002). The micropolitics of teacher induction: A narrative-biographical study on teacher socialization. Teaching and Teacher Education, 18, 105-120. doi:10.1016/S0742-051X(01)00053-1

Kitching, K., Morgan, M., \& O’Leary, M. (2009). It's the little things: Exploring the importance of commonplace events for early-career teachers' motivation. Teachers and Teaching, 15, 43-58. doi:10.1080/13540600802661311

Kyriacou, C., \& Kune, R. (2007). Beginning teachers' expectations of teaching. Teaching and Teacher Education, 23, 1246-1257. doi:10.1016/j.tate.2006.06.002

Lampert, M., \& Clark, C. M. (1990). Expert knowledge and expert thinking in teaching: A response to Floden and Klinzing. Educational Researcher, 19, 21-23. doi:10.3102/0013189X019005021

Lortie, D. (1975). Schoolteacher: A sociological study. Chicago: University of Chicago Press.

Maskit, D., \& Dickman, N. (2006). From "student-teacher" to "becoming a teacher”-Story of a beginning. In A. Kupperberg, \& O. Olstein (Eds.), Discourse in education (pp. 21-49). Tel Aviv: Klil Education Books with MOFET Institute.

Ministry of Education (2000). Policy Document, Jerusalem, Israel (In Hebrew).

Orland-Barak, L., \& Maskit, D. (2011). Novices "in story”: What firstyear teachers' narratives reveal about the shady corners of teaching.
Teachers and Teaching, 17, 435-450. doi:10.1080/13540602.2011.580520

Patton, M. Q. (2002). Qualitative research and evaluation methods (3rd ed.). Thousand Oaks, CA: Sage Publications.

Raosas, C., \& West, M. (2009). Teachers' beliefs about classroom management: Pre-service and inservice teachers’ beliefs about classroom management. International Journal of Applied Educational Studies, 5, 55-61.

Romano, M. (2004). Teacher reflections on "bumpy moments" in teaching: A self study. Teachers and Teaching, 10, 663-681.

Romano, M. (2008). Successes and struggles of the beginning teacher: Widening the sample. The Educational Forum, 72, 63-78. doi:10.1080/00131720701603651

Salinitri, G. (2005). The effects of formal mentoring on the retention rates for first-year, low achieving students. Teachers and Teaching: Theory and Practice, 10, 663-681. doi: $10.1080 / 1354060042000304828$

Sánchez, E., Rosaes, J., \& Cañedo, I. (1999). Understanding and communication in expositive discourse: An analysis of the strategies used by expert and pre-service teachers. Teaching and Teacher Education, 15, 37-58. doi:10.1016/S0742-051X(98)00033-X

Schlichte, J., Yssel, N., \& Merbler, J. (2005). Pathways to burnout: Case studies in teacher isolation and alienation. Preventing School Failure, 50, 35-40. doi:10.3200/PSFL.50.1.35-40

Smith, K., \& Sela, O. (2005). Action research as a bridge between pre-service teacher education and in-service professional development for students and teacher educators. European Journal of Teacher Education, 28, 293-310. doi:10.1080/02619760500269418

Spindler, J., \& Biott, C. (2000). Target setting in the induction of newly qualified teachers: Emerging colleagueship in a context of performance management. Educational Research, 42, 275-285. doi:10.1080/001318800440605

Stanulis, R. N., Burrill, G., \& Ames, K. T. (2007). Fitting in and learning to teach: Tensions in developing a vision for a university-based induction program for beginning teachers. Teacher Education Quarterly, 34, 135-147.

Stoeber, J., \& Rennert, D. (2008). Perfectionism in school teachers: Relations with stress appraisals, coping styles, and burnout. Anxiety, Stress and Coping, 21, 37-53. doi:10.1080/10615800701742461

Stoughton, E. H. (2007). “How will I get them to behave?”: Pre service teachers reflect on classroom management. Teaching and Teacher Education, 23, 1024-1037. doi:10.1016/j.tate.2006.05.001

Strauss, A. L. (1987). Qualitative analysis for social scientists. Cambridge: Cambridge University Press. doi:10.1017/CBO9780511557842

Strauss, A., \& Corbin, J. (1994). Grounded theory methodology: An overview Chapter 17. In N. K. Denzin, \& Y. S. Lincoln (Eds.), Handbook of qualitative research (pp. 273-285). California: SAGE.

Sykes, G., \& Bird, T. (1992). Teacher education and the case idea. Review of Research in Education, 18, 457-521.

Veenman, S. (1984). Perceived problems of beginning teachers. Review of Educational Research, 54, 143-178. doi:10.3102/00346543054002143

Vonk, J. H. C. (1993). Mentoring beginning teachers: Mentor knowledge and skills. Mentoring and Tutoring: Partnership and Learning, $1,31-41$.

Vonk, J. H. C. (1995). Conceptualizing intern teachers' professional development: A base for supervisory interventions. Paper presented at the Annual Conference of AERA, San Francisco.

Weinstein, C. S. (1990). "Prospective elementary teachers" beliefs about teaching: Implications for teacher education. Teaching and Teacher Education, 6, 279-290. doi:10.1016/0742-051X(90)90019-2 